\title{
Philosophizing Tasawwuf: The Postmodern Cult of Sufism
}

\section{Dr. Iftikhar Shafi}

\begin{abstract}
The paper is a critical study of some relatively recent Western approaches to tasawwuf. These so-called post-structuralist approaches, the deconstructionist being chief among them, seem to extend the earlier orientalist attempts, as that of Henry Corbin, Reynolds Nicholson or Pervez Morevidge, of philosophizing tasawwuf, thus turning it into one among various other 'isms' conveniently available to the Western critical understanding. Reviewing Ian Almond's Deconstruction and Sufism and The New Orientalists, the paper argues that in their preoccupation with tracing apparent affinities between the deconstructive/ post-structuralist and the Sufi positions on the socalled 'metaphysics of presence', what such studies often overlook is the epistemological difference between these two discourses. It remains a matter of some detailed discussion, which the paper does propose to attempt, to see that these recent critical approaches in the West, despite their avowed project of announcing the demise of philosophy, still somehow remain essentially complicit with the tradition of thought they look to dismantle.
\end{abstract} I

There is a band of neo-orientalists around. And in their impressive presentation of tasawwuf, they are committing what I would term here as a 'violent' act of 'literary terrorism'. Lest my use of the terms 'violent' and 'terrorism' be confused with their more popular and prevalent political, militant and physical connotations these days, let me make a clarification right away. I have borrowed both these terms from a couple of the most representative postmodern thinkers, namely, Jacques Derrida and Jean-Francois Lyotard. The purpose of such a borrowing is manifestly to restrict the connotations of these terms to a strictly intellectual domain. Without any intention whatsoever of anyway belittling the enormity of slaughter, blasts, hijackings and wars, 'violence' and 'terrorism' in the physical domain, one could say that the two acts, in their intellectual, that is, literary and philosophical manifestations, may be far more subtle, insidious and penetrating than their physical counterparts. 'Fitnah is worse than slaughter', the Quran tells us (2: 191). Fitnah, Abdullah Yousuf Ali points out, can signify trial, temptation, tumult, sedition, oppression, even persecution as the 'suppression of some opinion by violence...' (n. 239, 89, my italics).

As one aim of this paper is to refresh in our hearts and memories the insistence of our Sufis that tasawwuf is not philosophy, it is significant to note that Derrida opens his essay Violence and Metaphysics, even before ruminating on the probable death of philosophy in the West, with a caption form Matthew Arnold's Culture and Anarchy. The quoted passage epitomizes the agony the West has gone through, and 
as I will argue, is still going through, in trying to deal with the 'unholy matrimony' of religion and philosophy, "the revelational and the rational", in Arnold's terms, Hebraism and Hellenism. The caption is worth quoting again: "Hebraism and Hellenism - between these two points of influence moves our (the Western) world. At one time, it feels more powerfully the attraction of one of them, at another time, of another; and it ought to be, though it never is, evenly and happily balanced between them' (parenthesis and italics mine). ${ }^{1}$

Through this caption, Derrida invokes and exploits Arnold's acknowledgement, referred to in the passage through my italics, of the unhappy encounter of the two legacies, the genesis of one being in Jerusalem and of the other in Athens, two genetically different and incompatible, heterogeneous, histories of philosophy and 'non-philosophy' in the West. 'Violence' for Derrida is the way philosophy 'opens history by opposing itself to non-philosophy', ${ }^{2}$ much in a similar gesture through which Samuel Johnson termed the Metaphysical poets' practice of 'yoking together heterogeneous ideas' as violent. Violence understood in a Derridian sense would be philosophy's attempt at dealing with problems which '[B]y right of birth ... (are) problems philosophy cannot resolve'. 'These questions', he writes, 'are not philosophical, are not philosophy's questions'. However Derrida, in his characteristic adamantine irony considers such questions as 'the only questions capable of founding the community... (of) philosophers'. ${ }^{4}$

So philosophy's meddling with issues even beyond its legitimate purview goes on. Thus in this paper we will see the ongoing attempt of philosophy at encroaching upon tasawwuf as a perpetuating act of 'violence', to use Derrida's phrase, as an act of 'militant theoretic'. If tasawwuf is non-philosophical, if it is not philosophy, then philosophizing tasawwuf must be taken as 'violence', 'as the necessity that the other not appear as what it is, that it not be respected except in, for, and by the same...,

Jean-Francois Lyotard (1926-98), in The Postmodern Condition (1979), arguably the most famous philosophical formulation of postmodernism, considers terror as an 'efficiency' which is derived 'from a "say or do this, or else you will never speak again"...':

By terror I mean the efficiency gained by eliminating, or threatening to eliminate, a player from the language game one shares with him. He is silenced or consents, not because he has been refuted, but because his ability to participate has been threatened (there are many ways to prevent

\footnotetext{
${ }^{1}$ Matthew Arnold, Culture and Anarchy, quoted here from Jacque Derrida, Writing and Difference (henceforth referred as $W \& D$ ), (London: Routledge, Third Indian Reprint, 2007) 97.

${ }^{2}$ Derrida, $W \& D, 97$.

${ }^{3}$ Ibid., 98.

${ }^{4}$ Ibid., 98

5 Ibid. , 109.

${ }^{6}$ Ibid. , 165.
} 
someone from playing). The decision maker's arrogance...consists in the exercise of terror. It says: 'Adapt your aspirations to our ends — or else'.

Before I go on to further establish the current neo-orientalist philosophizing of tasawwuf as 'terrorism' in Lyotardian terms, and also why I call this act of 'violent terrorism' as 'literary', let me address the question of the addressees, my own, and the likely and probable addressees of these new orientalists. My own addressees I deem to be those on the peripheries, people occupying or patrolling the border-lines, people for whom it has become necessary, perhaps obligatory in a sense, to know and understand modernity and postmodernity. They can't seem to live peacefully without this knowledge, for whom it is a part of their vocation to get familiar with every new 'ism' originating from the occident every now and then, people who, so to say, can not be content with a Keatsian 'that is all ye know on earth and all ye need to know'. These are, myself included, the ones who would want to be seen in 'intellectual' gatherings (the question of motivation for such presences I deliberately leave open).

As for the neo-orientalists, their 'beautifully crafted postmodernist idiom' (that's how S. Nomanul Haq characterizes Ebrahim Moosa's language), remains attractively inaccessible to even some of our most aspiring graduate, postgraduate students and research scholars, let alone a Sufi in a khanqah. These neo-orientalists, almost invariably all of them, seem to be crafting their idiom from a certain jargon that is prevalent among the Western intellectual community. This jargon is basically drawn from a host of theoretically intricate formulations in the disciplines of psychology, sociology, anthropology, primarily philosophy, and what not! The ones who feel to be 'absolutely' familiar with this jargon, I mean the postmodern neoorientalists themselves, give only that much damn about 'Sufism' (their own 'terrorist' reduction of the term tasawwuf, again in a strictly Lyotardian sense of 'terrorism'), as Ian Almond argues, as is useful for their own purposes of either critiquing modernity ${ }^{8}$ or proving tasawwuf to be aligned with the postmodernist harangue against the notion of an absolute center.

For those who are 'awfully' familiar with this 'beautifully crafted postmodern idiom', this highly philosophized presentation of tasawwuf offers a seductively deferred promise of meaning, the reader caught up in kind of suspense of expectation that one would experience in reading fiction (that's probably why most of these publications appear under the category of philosophy/literature given on the blurb!), waiting for a Godot who would never come, the point of meaning always deferred, and also differed (for as I attempt to do it, it is not difficult to point out the inner contradictions within these works). In other words the philosophical

\footnotetext{
7 Jean-Francois Lyotard, 'The Postmodern Condition: A Report on Knowledge', in From Modernism to Postmodernism: An Anthology, (ed.) Lawrence E. Cahoone (Malden: Blackwell, 1996) 502.

${ }^{8}$ Ian Almond, The New Orientalists, Postmodern Representations of Islam From Foucault to Baudrillard (London: Tauris, 2007) 4.
} 
reductions of tasawwuf seem to be deliberately crafted on the Derridian model of differánce.

I am alive to the fact that by now my reader would be ready to accuse me of an attempt at using the same kind of jargonized language, the stylized postmodernist idiom, elliptically truncated expressions, long sentences with loosened grammatical structure, that I am using the same terms, playing according to the same rules of the game I intend to critique. And I accept the allegation. I don't want to play a 'terrorist' here. I am not writing primarily on tasawwuf but on a certain violent attempt at reducing tasawwuf to philosophical categories. What I am attempting here is, in Lyotard's words, 'a renunciation of terror', by observing and respecting the principle "that any consensus on the rules defining a game and the "moves" playable within it must be local...agreed on by its present players... ${ }^{9}$ I repeat, I am not primarily talking about tasawwuf here, but a certain representation of it. I must frankly admit my incompetence for any such ambitious attempt. Were I to do that, I would certainly be more cautious of playing into the hands of postmodernism. And whenever in this paper I try to do that, that is, directly say anything on behalf of tasawwuf, I will take every possible care to do this via those who have an established identity as Sufis. But the practice of playing into the postmodern hands, I am afraid, seems to be too rampant these days, characterizing in one way the postmodern condition itself: that people too small in stature dare talk about men too great for them.

'Rumi is relentless in his constant emphasis on the irreducibility of inner meanings to their contextual and relational representation. However, whether he himself is entirely successful in always transcending his cultural context is a matter of debate ${ }^{10}{ }^{10}$ When a Mahdi Tourage is seen thus questioning the claims to universality of Rumi instead of relating to Rumi in Rumi's own terms, forcing upon the Mathnawi a reading couched in Foucault's or Lacanian 'hermeneutics of eroticism', that is where the postmodernist take on tasawwuf becomes 'terrorist' in a Lyotardian sense. Such Foucaultian, Lacanian or Derridian hermeneutics, no matter how much it tries to locate itself in an anti-platonic, anti-philosophical stance, ultimately remains, as Paul Ricoeur would have it, a 'hermeneutics of suspicion', as the only hermeneutics available to philosophy. One should heed Rumi himself on such philosophical hermeneutics of suspicion and its incompatibility with any interpretation in tasawwuf:

The philosopher in his (vain) thought and opinion becomes disbelieving: bid him go and dash his head against his wall!

The philosopher who disbelieves in the moaning pillar is a stranger to the senses of the aulia.

\footnotetext{
${ }^{9}$ Ibid. , 504 .

${ }^{10}$ Mahdi Tourage, 'Hermeneutics of Eroticism in Rumi', in Comparative Studies of South Asia, Africa and the Middle East (Duke University Press, vol. 25, no. 31, 2005) 616.
} 
Whoever hath doubt and perplexity in his heart, he in this world is a secret philosopher.

He is professing firm belief, but sometime or other that philosophical vein will blacken his face.

Take care, O ye Faithful! For that (vein) is in you! In you is many an infinite world. For fear of this, anyone who has the fortune of (holding) this Faith (Islam) is trembling like a leaf.

The Abdal have certain terms of which the doctrines of reason are ignorant. ${ }^{11}$

II

You are judging from (the analogy) of yourself, but you have fallen far, far (away from truth). Consider well.

Do not measure the actions of holy men by (the analogy of) yourself, though sher (lion) and shir (milk) are similar in writing.

Rumi, The Mathnawi, I/ 246, 264

Perhaps it would be more meaningful to begin reading Ian Almond's The New Orientalists from the last sentence of his book (in any case it does not really make much of a difference if one approaches any text written in beautifully crafted postmodern idiom' either from its beginning or from its end-one remains, as the postmodern slogan goes, 'always in the middle', in Ebrahim Moosa's terms, in the dihlizian space).

The concluding sentence, as expected, summarizes the thesis of the book, but rather unexpectedly perhaps also for the writer also contains a confession:

That in attempting to write about the other, we invariably end up writing about ourselves has become a cliché of Oriental's studies - 'extending the Empire of the same', as Levinas called it;

${ }^{11}$ Jalal al-Din Rumi, The Mathnawi, (ed. \& trans.) Reynold A. Nicholson, (Karachi: Darul Ishaat, 2003) I/ 3278, 80, 85-87, 89, 3409, pg. 178-185. The last line here in Nicholson's edition reads aqwal, as the rhyme of abdal in the first line. In the texts of Kaleed [see Mawlana Ashraf Ali Thanawi, Kaleed-e-Mathnawi, (Multan: Idarah Taleefat-e-Ashrafiyah, n. d.) vol. 1, 547], Miftah al-Ulum [see Muhammad Nazir Arshi, Miftah al-Ulum, (Lahore: Sheikh Ghulam Ali, n. d.) vol. 4, 132], Ilham-e-Manzum [see Maulawi Ferozuddin, Ilham-eManzum, (Lahore: Feroz Sons, n. d.) vol. 1, 396), the rhyme reads uqqal. The text of Haji Imadadullah Muhajir Makki, asa in Nicholson's edition, also reads aqwal, but in the margin Haji Sahib in parenthesis interprets aqwal as uqqal, that would translate as 'the people of reason' [see Mathnawi Mawlawi Maanawi, (Quetta: Amir Hamza Kutubkhanah, n. d.) vol. 1, 306). Nicholson understands aqwal as 'doctrines' and adds a parenthetical interpretation: 'of external religion', which betrays an orientalist tendency of considering tasawwuf as something transcending the boundaries of shariah, the Islamic law. 
what remains surprising is that so many of the figure responsible for delineating and delivering and demonstrating this situation of epistemological finitude so visibly fail to escape it in their own work. ${ }^{12}$ (my italics)

Nothing could be truer for Almond himself. The book obviously is neither about Islam nor about tasawwuf. It is about a certain 'representation of Islam in postmodern texts', both literary and philosophical, from Foucault to Baudrillard. When Almond tells us that 'Nietzsche says very little about what Islam is, but only what it is $n o t t^{13}$, or Orhan Pamuk is actually using the Sufi tradition 'to illustrate his own secular beliefs concerning the illusion of the self ... and to undermine tradition, employing one aspect of Islam to deconstruct another, ${ }^{14}$, he actually makes his own writing open to a similar sort of criticism. This he implicitly acknowledges in the introduction of the book by saying that '[O]ne of the main effects of this examination (of the new orientalist postmodern depiction of Islam and tasawwuf) will be to culturally re-locate and delimit the critique of modernity much the same way such a critique historicized modernity itself' ${ }^{15}$. So if the postmodern 'new orientalists' are using Islam and tasawwuf for their own critique of modernity, Almond could be said to be using Islam and tasawwuf to critique the critique of modernity itself.

And what to say about my own paper? Having already acknowledged that I am not primarily writing on tasawwuf, but on a certain representation of it, am I not using tasawwuf to critique a critique of a critique? Am I not 'caught in ... (the same philosophical) circle ${ }^{16}$ ? to use Derrida's words (with my own parenthetical insertion), and making also myself vulnerable to the postmodern borrowings that would allow, as Derrida points out, 'to destroy each other reciprocally" ${ }^{17}$ ? To step 'outside philosophy', one must argue after Derrida, 'is much more difficult to conceive than is generally imagined by those who think they made it long ago.... and who in general are swallowed up...in the entire body of discourse which they claim to have disengaged from it'. ${ }^{18}$

But for me, I would still wish to disengage myself, despite my present venture, from this vicious circle of 'the destroyers and the destroyed', not by any ambitious claims to thorough knowledge, but by humble concessions of a few acknowledgements. To acknowledge firstly, that every critique that uses a certain discourse as an underlying thematic to talk about a certain other discourse, necessarily contains at least an implicit understanding of the used discourse, even if that implicit

\footnotetext{
${ }^{12}$ Almond, The New Orientalists, 203

${ }^{13}$ Ibid., 15.

${ }^{14}$ Ibid., 121.

${ }^{15}$ Ibid. , 4.

${ }^{16}$ Derrida, $W \& D, 355$.

${ }^{17}$ Ibid., 356.

${ }^{18}$ Ibid., 359.
} 
understanding does not appear in the critique explicitly, even if it can be seen only through the marginal crevices, through the unconscious, of the text. This implicit understanding can also be made explicit through an inter-textual approach, that is, by relating a given text of the critique to the context of other texts around it, in Derrida's words, within a 'syntax and a system' of that critique. ${ }^{19}$

Secondly, to acknowledge that what we call the 'use of terms' must be understood, as Derrida points out for the discourse of philosophy (he uses the word 'concepts' instead of terms), 'within the inherited concepts of metaphysics. Since these concepts (read terms) are not elements or atoms, and since they are taken from syntax and a system, any particular borrowing brings along with it the whole of metaphysics' ${ }^{20} \mathrm{~A}$ 'term' is not simply a word, a sign positive in a Saussurian sense, but gives its meaning only within the syntax or a system (called metaphysics by Derrida). It must be pointed out that many have been relating tasawwuf to Platonism or neo-Platonism simply because they find a similar vocabulary employed here and there, without properly acknowledging the distinct 'universe of discourse' within which these terms operate. In his commentary on Rumi's line, 'the abdal have certain terms...', Mawlana Ashraf Ali Thanawi points out that the word istilah (term) here does not mean 'term' in a 'terminological' sense, for it is neither difficult nor a matter of knowledge to understand it thus, like words in a dictionary these terms are also given in the books related to the art (of tasawwuf), rather what is meant by terms here are those realities of excellence which these dictionary or terminological words refer to. Since these (excellences) are a matter of taste (experience/ dauq) that is why reason is insufficient to understand their reality...for instance somebody heard from an arif about the love of Allah, and understood it as a certain tendency of heart that is already there in him, so he counted himself (in his own understanding) among the lovers (of Allah). Actually the referent was to a certain condition that cannot be known without being had. Or for example, a child not having reached adulthood considers the pleasure of sexual intercourse as that of eating a sweet, and starts considering himself as experiencing the pleasure of intercourse... ${ }^{21}$ Syed Shah Muhammad Zauqi in Sirr-e-Dilbaran also mentions that 'there also exists in this world a group of people who have only a bookish relationship with tasawwuf. They are self-styled Sufis. They make exaggerated use of the terms of the Sufis, needed or unneeded. They are still incarcerated in their senses, haven't even stepped into the path. They are caught up in the futile attempt at flying through their bookish information and rational indulgences. These people are...incapable of understanding the true meaning and subtleties of these terms. Actually most often, their futile attempts prove to be too harmful for them.

\footnotetext{
${ }^{19}$ Ibid., 355.

${ }^{20}$ Ibid., 355-56.

${ }^{21}$ Ashraf Ali Thanawi, Kaleed-e-Mathnawi, vol. 1, 547.
} 
Tasawwuf is a unity of theory (ilm) and practice (amal). Unless one steps into the domain of practice, nothing could be had either from tasawwuf or from its terms'. ${ }^{22}$

The final acknowledgement is that of being on the periphery, of being 'in the middle'. But one can only be in the middle of something, some polarities, of inside and outside. This space of in-between-ness, in Ebrahim Moosa's terms, the dihlizian space, is not neutral. Seeming to be in such a space, my fellow occupants and I have the vantage point to look at both the sides, the inside and the outside, and looking at the former we say, to evoke the Qur'anic call of 'the men on the Heights', 'Peace on You' (7: 46), looking at the latter, 'Our Lord! Send us not to the company of the wrong-doers' (7: 47). Living in a complex and 'mobile force field', to use Ebrahim Moosa's words, of modernity, post-modernity, and Islam, we would like to be associated with those who, in the words of the Quran, 'acknowledge their wrongdoings', who have 'mixed an act that was good with that was evil' (9: 102), hoping for Allah's mercy and forgiveness. Being on the peripheries, we would desire to 'enter Islam whole-heartedly' (2: 208), to be the insiders.

But our neo-orientalists do not seem to entertain any such acknowledgements. Their implicit understanding of tasawwuf, as it comes out either through an inter-textual reading or through the 'unconscious' of their texts, suggests a violent subordination of tasawwuf to philosophy. Secondly, they freely confuse the terms of tasawwuf with philosophical terms. Ian Almond, for instance, actually considers 'confusion' in its etymological sense of 'flowing together' or 'removing the boundaries/borders/ distinctions' as something very desirable and common in both deconstructive and Sufi thought. ${ }^{23}$ Despite apparently acknowledging their postmodern positioning of 'in between-ness', they still make unwarranted statements about tasawwuf with an air of an insider's authority.

\section{Before going ahead, let us go a little backwards}

It has been mentioned earlier that the thesis and conclusion of Almond's The New Orientalists as given in the last sentence of his book is that the writers he has discussed from Foucault to Baudrillard, whom he calls the 'new orientalists', actually use Islam and tasawwuf for their own postmodernist critique of modernity without attempting to understand these by themselves, while the people who point out this postmodernist error, like Almond himself, are ultimately caught up in the same reductionist web. This last remark from Almond could still have been taken as a belated realization, as a confession, as some kind of a 'growth' in Almond's own approach towards tasawwuf that he betrayed years back in his 2004 book Sufism and Deconstruction, had it not been the case that there are copy-pasted passages from the earlier to the later work, and also that the more recent of the two works still

\footnotetext{
22 Syed Shah Muhammad Zauqui, Sirr-e-Dilbaran (Lahore: Al Faisal, 2005) 35. English translation from original Urdu is mine.

${ }^{23}$ Ian Almond, Sufism and Deconstruction, A Comparative Study of Derrida and Ibn Arabi, (London: Routledge), 39.
} 
betrays the retention of his earlier opinion that tasawwuf can be related to the postmodern philosophy via Christian mysticism. Let us go into some detail of these neo-orientalist traces.

Copy-pasting from an earlier work may not be objectionable in itself. Any intellectual growth, after all, may have some kind of a link with an earlier opinion. But the passages under reference here reveal that the questions they raise are still left under-answered in their more recent appearance as they were left thus earlier. The series of copy-pasted questions are 'inspired' by the fact that Derrida refuses to talk about tasawwuf, while he talks a lot about Christian mysticism:

[W] hat exactly is the difference between the Greek/Christian negativity Derrida is willing to talk about and the... Islamic version...he feels he cannot? Is Derrida hinting at a certain deconstructive success in ... Sufi mysticism, a success not to be confused with (its) Greek/ Christian counterparts and all their Hellenized dependency on logos and the epekeinia tes ousia...

[W] hat is the real reason for Derrida's decision 'not to speak of ... Islamic tradition ... in his counter-deconstruction of negative theology ....? Why does Derrida choose to stay in Christian Europe $?^{24}$

In both the books, without ever dealing squarely with the significance of any of these important questions, Almond offers another series of speculative 'perhapses' and 'may be's' as probable reasons for Derrida staying away from meddling with tasawwuf, and for Almond all these probable reasons are 'only straight forward' and 'not complex':

[M] ay be Derrida simply does not know enough about...Ibn Arabi or Maulana or Suhrawardi. Perhaps he can't read Arabic... Perhaps he was too enticed by the possible genealogy of three figures such as Pseudo-Dionysius, Eckhart and Heidegger (each of whom has read his predecessor) to wander off into the strange deserts of ... Persian esotericism. There even may be a possibility that Derrida, in distinctly under-constructed moment of political correctness, was more attracted by the deconstruction of a European Christian tradition than a non-European Islamic ... one; after all his talk of 'a Europe united in Christianity' and the 'logocentric impasse of European domesticity', perhaps Derrida more pressing need to deconstruct Euro-Christian logo-centricism than their Islamic ... equivalents. ${ }^{25}$

\footnotetext{
${ }^{24}$ Ibid., 4, The New Orientalists, 43-44.

${ }^{25}$ Ibid., 4-5, The New Orientalists, 44.
} 
Interestingly, Almond does not seem to be much bothered about determining the reason for Derrida's hesitation to talk about tasawwuf. In both the books, the question of the significance of the reasons behind Derrida's reluctance receives an offhand dismissal: 'Whatever be the reasons... ', thinks Almond, and then continues to observe that Derrida's is a 'mystical' silence on the issue. The implication would be that the mystic cannot talk about the other, and since tasawwuf is 'far too radically autre' for Derrida, he remains silent about it. ${ }^{26}$ In The New Orientalists, Almond draws a conclusion pertinent to his immediate project, that is, Islam remains at the margins of Derrida's discourse: 'Derrida's faint anxiety at not having talked of ... Islamic mysticism betrays an awareness of Islam's marginal status ... ',27 a conclusion too obvious even to be stated.

But in his earlier work Sufism and Deconstruction, Almond seems to ignore even such a tautological conclusion. Sufism and Deconstruction is a book 'worth reading' (166 pages cost $£ 105$ on Amazon.com ) in which Almond scatters bezels of his own wisdom in Ibn Arabi's name (please recall the caption of this section of my paper as a comment). Tasawwuf and philosophy are finally brought to be 'confused' (in Almond's etymologically desirable sense), finally brought to gel together 'as different fragments belonging to the same, long-shattered vase ${ }^{28}$ (just like Henry Corbin earlier informed us that along with Sheikh-e-Akbar, Ibn Aflatun was also one of Ibn Arabi's surnames, but never bothers to say whoever called him so, Almond does not explain how this 'long-shattered vase' must have looked like!)

Here he seems to be using Derrida's 'mystical' silence as some kind of a relationship with tasawwuf Derrida can be forced into. What if Derrida never meddled with tasawwuf, he did in any case with Christian mysticism. This problematic premise seems to suffice for Almond to trace similarities between deconstruction and 'Sufism'. In doing so, he even refuses to give the terms of tasawwuf any special status. Utterly disregarding the need for any exclusive treatment of Sufi language, he informs us that Ibn Arabi's work 'far from being some obscure Sufi esotericism encrypted in mystical Eastern terminology, actually asks the same (my emphasis, recall Almond quoting Levinas' phrase, 'extending the Empire of the same'!) questions and moves in some similar directions as a number of familiar figures in the West'. ${ }^{29}$

Completely forgetting, as if, his earlier question as to "what exactly is the difference between the Greek/Christian negativity, Derrida is willing to talk about and the ... Islamic version ... he feels he cannot' (my italics), ${ }^{30}$ Almond is quickly attracted by the similarities between Ibn Arabi and 'key figures in the Western philosophical

\footnotetext{
${ }^{26}$ Ibid., 5, The New Orientalists, 45.

${ }^{27}$ Almond, The New Orientalists, 46.

${ }^{28}$ Almond, Sufism and Deconstruction, 2.

${ }^{29}$ Ibid. , 5 .

${ }^{30}$ Ibid., 3-4.
} 
tradition, ${ }^{31}$ The chief among these key figures in the Western philosophical tradition (it is revealing that Almond does not see any point in distinguishing between the Christian mystical and the Western philosophical tradition!) is Meister Eckhart, who, in Almond's words, 'makes itself felt throughout ... as a phantom third figure in ...comparative study of Derrida and Ibn Arabi. ${ }^{32}$

Henry Corbin earlier called Ibn Arabi ibn Aflatun (Plato's son) on God knows whose authority. For calling Ibn Arabi 'Meister Eckhart of the Islamic tradition' Almond conjures up mainly two (but essentially one) authorities, first a group of neo-orientalists like R. Netton, Dom Sylvester Houdehard and Ralph Austin, and secondly himself. Almond thinks that even if you have not read a single word from these neo-orientalists, 'it is not difficult to see why so many scholars link them (Ibn Arabi and Eckhart) together' (my parenthesis). ${ }^{33}$ What is difficult to see though for these neo-orientalists is the basic difference between any figure from Sufi tradition and one who represents the Western philosophic-mystical tradition, a difference whose acknowledgement would subsequently render all the apparently 'striking resemblances' meaningless. Rumi reminds us:

Consider hundreds of thousands of such likenesses and observe that the distance between the two is (as great as) a seventy years' journey.

If both resemble each other in aspect, it may well be (so): bitter and sweet water have (the same) clearness.

Who knows the difference except a man possessed of (spiritual) taste? Find (him): he knows the sweet water from the brine. ${ }^{34}$

The main difference between the Sufi tradition and the Western philosophicmystical tradition is the Sufis' unflinching, uncompromising belief in al-tawhid, the unity and oneness of Allah, as Imam Qusheri discusses in detail in his Risalah Qushayriyyah. In Tasawwuf aur Sirriyat (Tasawwuf and Mysticism), one of the highly readable books on the topic, the late Professor Latifullah points out that in Ekhart's work there is an amalgamation of the Aristotelian philosophical elements and the mysticism of Pseudo-Dionysius. With his existentialist tendencies (that is probably why Heidegger was so fascinated by him) Eckhart held the belief that God created his Son as a partner in His eternity. The Son is equal to God. The Son created the universe. Professor Latifullah thinks that Eckhart is not even aware of the difference between tawhid (unity) and shirk (ascribing partners to God). ${ }^{35}$

\footnotetext{
${ }^{31}$ Ibid., 5 .

${ }^{32}$ Ibid., 5 .

${ }^{33}$ Ibid., 5.

${ }^{34}$ Rumi, The Mathnawi, I/ 271, 275, 276.

${ }^{35}$ Latifullah, Tasawwuf aur Sirriyat, (Lahore: Idarah Saqafat-e-Islamiyyah, 2005) 84-85. The English paraphrase from original Urdu is mine.
} 
One wonders why Hossein Nasr, who acknowledges that 'the several intellectual perspectives cultivated in Islam all conform(ed) to the doctrine of unity (altawhid)', still thinks that one can see in 'Plato and Pythagoras a confirmation of the Islamic doctrine of al-tawhid, ${ }^{36}$ A more elaborate and frank account of the Platonic 'confirmation' of belief in the sense of revealed religions can be found in the writings of the Archdeacon of Westminster, Adam Fox, and this should also help throw some light on Christian mysticism's turning to 'Greek/Christian negativity' (Almond's term). In his book Plato and the Christians, Adam Fox presents an astonishing definition of a believer via Plato:

Plato's temperament was religious, and he probably accepted all these different divinities without much reserve. He slides from writing of 'God' to 'a god', from 'a god' to 'the gods', and back again very easily ... In one of the letters ascribed to him there is a curious sentence where he is made to say that at the beginning of his serious letters he will put the word 'God', but 'gods' at the beginning of his less serious ones (Epistles, XIII 363 B). This suggests that he thought, or was thought to think, a belief in gods subsidiary to a belief in God ... He admits without any precise definition the power and authority of God, of gods, of demons kind and cruel, of fortune, and of the Good. He sees nothing inconsistent in being theist, monotheist, and polytheist at the same time.

After making these honest acknowledgements, the Archdeacon comes up with a remarkably astonishing conclusion: ' $\ldots$ of such a man we should probably have to be content to say that he was a believer'. ${ }^{37}$

Agar inast rasm-e-doost dari, Iqbal would say on this, be divar-e-haram zan jam-omina (If these are the terms of friendship/ then break the cup and the goblet against the wall of the harem).

But Nasr would insist that "[W]hen Iqbal calls Plato "one of the sheep", he is following more the interpretation of Platonism by Nietzsche than by the Islamic philosophers themselves... ${ }^{38}$ Why would Iqbal, one could ask Mr. Nasr, for his opinion on Plato, rely more on Nietzsche, one who in his frequent associations between the Prophet Muhammad and Plato offers to us, as Almond points out, the Prophet Muhammad as an Arab Plato, 'who had always considered Plato' to be an 'instinctive Semite' (Semite von Instinkt) and a 'symptom of decadence' (VerfallSymptom).${ }^{39}$ Why shouldn't one trace the origin of Iqbal's opinion to the Sufis

\footnotetext{
${ }^{36}$ Seyyed Hossein Nasr, 'The Teaching of Philosophy', in Philosophy, Literature and Fine Arts, (ed.) Seyyed Hossein Nasr, (Jeddah: Hodder and Stoughton, 1982) 5-7.

${ }^{37}$ Adam Fox, Plato and the Christians (NY: Philosophical Library, 1957), 21.

${ }^{38}$ Ibid. , 7.

${ }^{39}$ Almond, The New Orientalists, 18-19.
} 
themselves, who are not exactly 'Islamic philosophers', to Shams, Rumi's master, who would contemptuously reject Plato's claims to love: 'the perfect philosopher was Plato. He lays claim to love...Are these the words of the accepted? Fire should come down over your head and face, ${ }^{40}$ or to Rumi himself who would consider Plato 'still outside the palace' $(D$ 5141), 'if love's pulse does not beat within a man, let him be Plato, he is but an ass' ( $D$ 12330).

For Nasr it is only modern Western philosophy that may be un-Islamic, but the ancient is not. He thinks that '[T]he study of Greek thought according to the Islamic intellectual tradition and independent of its Western interpretation is crucial for the Islamic confrontation with modern Western philosophy itself ${ }^{41}$ He analogizes the doubt and skepticism which for him only modern Western philosophy, and not the ancient classical, is capable of generating among the educated Muslims, as 'snake bite', but thinks that 'the cure for the snake bite is the poison of the snake itself...The best anti-dote against the errors (of philosophy) can be found in the criticisms made in the West itself'. Rumi rather would think otherwise:

In the plain where this fresh (virulent) poison grew, there has also grown the antidote, $\mathrm{O}$ Son.

The antidote says to you, 'Seek from me a shield, for I am nearer than the poison to thee.

Her (philosophy's?) words are magic and thy ruin; my words are (lawful) magic and the countercharm to her magic. ${ }^{42}$

The best antidote to philosophy is not philosophy itself, rather for Rumi it would be the words of the Sufis, what he calls sukhan-e-naqd (the immediate/cash speech). These are the people with a firm belief in the oneness of Allah and the finality of the Prophet-hood of Muhammad. These are the people who are the servants of God. 'A single one of God's servants', says Shams Tabrizi, 'can empty Plato of all those sciences. He can do it in a minute'. ${ }^{43}$ The essential aim of every Muslim, one should say, is to become a true servant of Allah, and any 'confrontation with the Western philosophy', any apologetic or defensive discourse should at the most be taken as removing any possible hindrances towards achieving this goal. Should I even ask this question what would be more conducive towards strengthening one's faith, sitting in a philosophy class, or being in the company of the servants of Allah, the aulia? If one could agree with Nasr's apparent tendency of considering Islamic perspectives as merely 'intellectual', then philosophy could certainly be encouraged to take a more integral role in the matters of faith and belief.

\footnotetext{
${ }^{40}$ Shams Tabrizi, Maqalat, (Me and Rumi) trans. William Chittick (Lahore: Suhail Academy, 2005), 64.

${ }_{41}^{4}$ Nasr, 'The Teaching of Philosophy', 8.

${ }^{42}$ Rumi, The Mathnawi, III/ 4076-78.

${ }^{43}$ Shams Tabrizi, Maqalat, 68.
} 
Coming back to Almond, one observes a similar connivance from the essential epistemological distinction between tasawwuf and philosophy, between knowledge and an experience coming out of faith in unity, and those coming out of a confused diversity of sources, divinities instead of the Divine. One could imagine the crooked and cracked edifice of 'striking resemblances' (and also what part of one's being these resemblances mostly strike) between tasawwuf and philosophy that is built upon an awry foundation.

\section{III}

Let us feel for some protruding parts of this edifice, some examples outstanding for their audacity.

In a characteristic neo-orientalist gesture of subordinating tasawwuf to philosophy, Almond seems to maintain that not only Ibn Arabi can teach us how to read Derrida but the possibility is also the other way round (he says this in the form of a rhetorical question). ${ }^{44}$ The desire to present Ibn Arabi in particular, and by default tasawwuf in general, as non-conformist, iconoclastic, anti-traditional seems to be so strong that it eclipses for Almond a more obvious and a more plausible idea, already pointed out by other critics, of relating deconstruction to the Jewish thought itself, especially its mystical side of Kabbalah, on which Derrida, just like his refusal to talk about tasawwuf, also refuses to speak.

This desire of yoking together heterogeneous discourses allows Almond to make critically and even factually and historically incorrect statements: 'Neither of the two (Ibn Arabi and Derrida) seems willing to attach their writings to a particular school of thought or tradition'. This certainly may be considered as an outrageously bold statement for Ibn Arabi, but even for a philosopher like Derrida this cannot be said to be entirely true. No matter how much deconstruction poses to be a departure from the Western philosophic tradition, it still retains the intellectual and rational strain of this tradition. Here is Derrida's own way of relating deconstruction to the history of Western philosophy: 'This moment of doubling commentary (deconstruction) should no doubt have its place in a critical reading. To recognize and respect all its classical exigencies is not easy and requires all the instruments of traditional criticism'. ${ }^{45}$ Herman Rapaport quotes Derrida to support the view that 'deconstruction is a critical method within the philosophical tradition': 'without this recognition and this respect, critical production would risk developing in any direction at all and authorize to say almost anything, ${ }^{46}$

As for Derrida, Almond tries to sequester him even for the critical lineage Derrida suggests for himself as a deconstructionist. As Almond rightly points out, Derrida considers 'even the trinity of Nietzsche, Freud and Heidegger ... the initiators of the

\footnotetext{
${ }^{44}$ Almond, Sufism and Deconstruction, 3.

45 Derrida, Of Grammatology, trans. G. C. Spivak, (Baltimore: Johns Hopkins University Press, 1975), 158.

${ }^{46}$ Ibid., 158.
} 
dissolution of Western metaphysics' remaining 'trapped in a kind of circle'. ${ }^{47}$ But the question is whether by pointing out of the complicity of the critique of metaphysics with metaphysics itself, Derrida is claiming for himself a place for standing outside the earth to overturn it with a lever?

In a bid to prove Ibn Arabi being outside the tradition, Almonds quotes a passage from Ibn Arabi that nowhere suggests the derived conclusion, and ironically he takes this passage as 'probably the best example' of Ibn Arabi critiquing 'practically every thinker ... (he) encounter(s)':

O Muhammad, I created my creatures and summoned them to Myself, but they differed among themselves with regard to Me. One group among them claimed that Ezra was my Son (IX: 30), and that My hand is fettered (V: 64-69). These are the Jews. Another group claimed that the Messiah is My Son (IX: 30), that I had a wife and child. These are the Christians. Another group gave Me partners. They are the idolaters. Another group gave Me a form. They are the corporealists (the Mujassima). Another group made Me limited. They are the Mushabbiha. Another group made Me non-existent. They are the Mu'attila. And there is another group who claim that I shall not be seen in the hereafter. They are the Mu'tazilites. ${ }^{48}$

A conspicuous example of 'violence' and 'terror' is Almond's confusion of Derrida's term differance and Ibn Arabi's term al haqq. The issue problematic in such a comparison is that despite giving lip-service to the fact that Derrida's philosophical and Ibn Arabi's spiritual gestures are not identical, Almond in the same breath insists that these gestures 'evolve according to the same structure' ${ }^{49}$ and despite their different 'constitution' they result in a similar sort of 'confusion'.

I must repeat that what matters is not simply the pointing out of the 'uncanny' (as Almond calls them) similarities between the philosophical and the Sufi expressions (one can always compare apples and oranges for that matter) but the significance and implications of those comparisons. As for the apparent similarities one can find passages not only in Ibn Arabi but also in other Sufis like Rumi who would at times talk about God in a way that would look 'uncannily similar' to Derrida's exposition of differance. Here is such an example, first a passage from Derrida on differance. According to Derrida differance is

... a structure and a movement which can not be conceived on the basis of the opposition of presence/absence. Differance is the

\footnotetext{
${ }^{47}$ Ibid., 9.

${ }^{48}$ Ibid., 8 .

${ }^{49}$ Ibid., 10

${ }^{50}$ Ibid., 37.
} 
systematic play of differences, of traces of differences, of the spacing [es pacement] by which elements refer to one another. ${ }^{51}$

In Fihi ma Fih Rumi says:

He (God) can not be qualified by presence or absence, for it would necessarily follow that an opposite proceeds from an opposite in that it would be necessary in the state of absence for Him to be the creator of presence, and presence is the opposite of absence. So also in the state of absence. Opposite can not be said to proceed from opposite, and God can not be said to create His like, because He says, 'He has no like'. If it were possible for like to create like, then a state would exist without there being a cause and a thing would have created itself. Both propositions are untenable. ${ }^{52}$

Immediately after saying this, Rumi announces what one may call here the epistemological break, a point from where, despite its apparently close resemblances with Derrida's notion of differance, the Sufi discourse takes off to a domain where the deconstructionist critical categories lose their operational efficacy: 'when you have come this far, stop and apply your self no more. Reason has no further sway: when it has reached the edge of the sea, let it halt'. ${ }^{53}$

Derrida, as Almond himself points out, was himself never aware of the possibility of such comparisons, but in Almond's own words, Derrida thought that 'we should not be deceived by' such apparent similarities. ${ }^{54}$ And rightly so. One could think that Derrida understood philosophy much better than its neo-orientalist users. But Almond does not look like taking even Derrida on his word, let alone Ibn Arabi. Despite Derrida's own warnings, Almond continues to trace similarities. As has been pointed out, this irresistible impulse to confuse philosophy and religion might have been more plausibly accommodated in tracing the origins of such expositions as that of differance in onto-theological systems, that is, religious systems infected already by philosophy, like the Jewish Kabbalah. But whenever such an echo comes, and it comes rarely in Almond, he quickly rejects such comparison between deconstruction and the Jewish mystical thought as a 'temptation', and in such cases prefers to keep Derrida to philosophy proper only: 'Although one might be tempted here', he talks about the unnamability of differance, 'to think of the Hebrew unnamable ... Derrida is actually alluding to Heidegger'. ${ }^{55}$

\footnotetext{
${ }^{51}$ Derrida, Positions, trans. Alan bass (Chicago: University of Chicago Press, 1981)

${ }^{52}$ Rumi, Fihi ma Fih, trans. W. M. Thackston Jr., Signs of the Unseen, The Discourses of Jalaluddin Rumi (Boston: Shambala, 1999), 207.

${ }^{53}$ Ibid.

${ }^{54}$ Ibid., 30.

55 Ibid., 31 .
} 
Harold Bloom, an eminent and influential Jewish contemporary critic, one among five major Yale critics along with Derrida, de Man, Hartman and Hillis Miller, in his book Kabbalah and Criticism writes:

Western literary criticism has followed the paradigm provided by Aristotle and Plato, with later modifications of Christian Aristotelianism and Christian Platonism, down to the recent models provided by theories as diverse as those of W. K. Wimsatt and Northrope Frye. Out of an amalgam of Nietzsche, Marx and Heidegger, Freud, and the linguists, another paradigm is now coming from France, moving upon us like that apocalyptic crimson man of Edom that Blake both celebrated and feared. ${ }^{56}$

Bloom calls this new paradigm in Western literary criticism (which can to a large extent be taken as a philosophical subjugation of literature) as a 'Kabbalistic model'. If one objects here that relating deconstruction in particular and postmodernism in general to the Jewish thought somehow legitimizes their comparison with Islamic tasawwuf, for the Jewish thought is comparatively more rigidly monotheistic than Christian mysticism's Trinitarian compromise on monotheism on the basis of which Christian mysticism's mediation between tasawwuf and philosophy was earlier questioned in this paper, one could point out Bloom's thinking that 'Kabbalah went out and away (even) from the main course of Jewish religious thought (whatever may be the status of the Jewish religious thought's claim to monotheism is another matter) ${ }^{57}$ Kabbalah, Bloom informs us, is basically 'a blend of Neoplatonism and Gnosticism', ${ }^{58}$ that is, it is a highly philosophized discourse (and in that at least should not be considered much different from Christian mystical thought). In Bloom's opinion, it is 'more of an interpretative and mythical tradition' and it 'differs ... Eastern mysticism in being more a mode of intellectual speculation than a way of union with $\operatorname{God}^{59}$.

Bloom further tells us that Kabbalah is 'a way of an interpretation of Scripture that depends overtly upon an audacious figuration ... Kabbalah seems to me unique among religious systems of interpretation in that it is, simply, already poetry, scarcely needing translation into the realms of the aesthetic...More audaciously than any development in recent French criticism, Kabbalah is a theory of writing ... ${ }^{60}$

With figures like Marx, Freud, Lacan, Althusser, Bloom, Derrida, just to mention a few, Jewish contribution to the unfolding of the Western postmodern thought can hardly be more emphasized. It would be far more legitimate and meaningful; critics like Almond should be told, to relate concepts like differance to a Kabbalistic model

\footnotetext{
${ }^{56}$ Harold Bloom, Kabbalah and Criticism (NY: Continuum, 1975), 87.

${ }^{57}$ Ibid., 16, parenthetical insertions mine.

${ }^{58}$ Ibid., 62.

${ }^{59}$ Ibid., 47, italics mine.

${ }^{60}$ Ibid., 52.
} 
rather than to tasawwuf. Seen in this perspective, the violence in relating differance and al haqq should become clear enough.

Kabbalah, we are told, is a theory of writing, so is it an attitude towards death, a characteristic Jewish avoidance of death, of keeping it somehow at bay all the time, and the same might be said about Derrida's notion of differance, as the paper will argue. It is 'a power of mind', writes Bloom, 'over the universe of death'. ${ }^{61}$ For Bloom Kabbalah is an 'apotropaic litany ... warding off, defending against death'. ${ }^{62}$ Bloom clearly relates Kabbalah as a theory of writing to Derrida's theory of writing:

Kabbalah speaks of writing before writing (Derrida's "trace") ... Derrida, in the brilliance of his Grammatology argues that writing is at once external and internal to speech, because writing is not an image of speech, while speech is already writing, since the trace it follows "must be conceived as coming before being". Derrida says that "all Occidental methods of analysis, explication, reading or interpretation" were produced "without ever posing the radical question of writing", but this is not true of Kabbalah, which is certainly an Occidental method, though an esoteric one. ${ }^{63}$

Whenever in the book Almond examines the thinkers who have related Derrida's thought to Kabbalah, the aspect of considering Kabbalah, differance, and Derrida's whole theory of writing as a characteristic Jewish attitude towards death is neglected. This Jewish attitude towards death, the paper argues, in its contrast from the corresponding Sufi approach to the notion of death can serve in one way as establishing the epistemological difference between Derrida's neo-Kabbalistic postmodern notions and tasawwuf. When examining, for instance, Thomas Altizer's emphasis on 'the Jewish theological thinker in Derrida', Almond is reminded of the 'risks one always takes in offering religious interpretations of avowedly secular thinkers ${ }^{64}$, (what about relating Ibn Arabi and Derrida for creating 'an awareness of the theological provenance of some of its (deconstruction's) gestures'?). ${ }^{65}$

In order to see why Derrida's notion of differance should be related more to the Jewish/ Kabbalistic attitude towards death instead of Sufi understanding of al haqq, let us have a look at Derrida's theory of writing.

The emphasis we put on the word writing whenever talking about Derrida's theoráy is to suggest the special and unusual sense in which Derrida understands the process. For Derrida the process of writing as he describes it, rather becomes a metaphor for the whole human experience, what he calls 'experience-in-general', the experience of human consciousness. This is why Derrida's essay that can be

\footnotetext{
${ }^{61}$ Ibid., 47.

${ }^{62}$ Ibid., 52.

${ }^{63}$ Ibid., 52-53.

${ }^{64}$ Almond, Sufism and Deconstruction, 77.

${ }^{65}$ Ibid. , 131.
} 
taken as an announcement of the advent of postmodernism and the demise of whatever may be called humanism, modernity, traditional thought, 'metaphysics of presence', is titled as 'The End of the Book and the Beginning of Writing', where the Book becomes a metaphor for a certain way of traditional thinking and Writing stands for a way of thought that debunks and dismantles this traditional thought.

Derrida's account of writing, and hence of experience-in-general, differs from the classical accounts of writing in the West, chiefly in Derrida's inclusion in the debate of the issue of 'the possibility of death' of the addressee. The Western philosophical tradition, the metaphysics of presence as Derrida calls it, conceives writing, as in Condillac's account, as a means of communication to those who are absent. But this absence, Derrida points out, is ever determined in the classical accounts of writing as 'a progressive extenuation of presence' and 'is not exhibited as a break in presence ${ }^{66}$ (this is probably why when we teach writing to our language students we advise them to keep the audience, even if they be imaginary, always in mind). Derrida argues that for writing to be writing, it should function beyond 'the absolute disappearance of every determined addressee in general ${ }^{167}$
All writing ... in order to be what it is, must be able to function in the radical absence of every empirically determined addressee in general. And this absence is not a continuous modification of presence; it is a break in presence, 'death', or the possibility of 'death' of the addressee ... ${ }^{68}$

The same holds true for the writer himself: 'For the written to be written, it must continue to 'act' and to be legible even if what is called the author of the writing no longer answers for what he has written'. ${ }^{69}$

Until this condition of the absolute absence or 'death' of the addressee or the addresser is met, the classical preference of speech over writing can not be accepted. But this very condition is untenable within the confines of rationality, in other words, philosophical thought itself. Speech in classical accounts, like that of Plato in the Phaedrus, occurs in the presence of 'the fullness of intentional consciousness' as compared to writing, the bastard son of logos or rationality according to Plato, that is physically detached from its producer and acts in the form of external marks. The question is whether this fullness of intentional consciousness is ever possible. Just as the classical Western metaphysics suppresses the possibility of death for its conception of writing, its notion of consciousness and self knowledge is also ever conceived as a repression of death. The Cogito as consciousness bears within itself its own destruction for its fullness to exist:

\footnotetext{
${ }^{66}$ Derrida, Margins of Philosophy, trans. Alan Bass (Chicago: University of Chicago Press, 1981), 313.

${ }^{67}$ Ibid., 315.

${ }^{68}$ Ibid. , 315-316.

${ }^{69}$ Ibid., 316.
} 
If the possibility of my disappearance in general must somehow be experienced in order for a relationship with presence in general to be instituted, we can no longer say that the experience of the possibility of my absolute disappearance (my death) affects me, occurs to an I am, and modifies a subject, The I am, being experienced only as an I am present, itself supposes a relationship with presence in general, with being as presence. The appearing of the Ito itself in the I am is thus originally a relation with its own possible disappearance. Therefore, I am originally means I am mortal..$^{70}$

This is all rational, quite logical stuff, one could say. But one thing that the argument makes clear is that any claim to self-knowledge within a philosophical and rational paradigm is bound to remain illusory. What we locate through Derrida in the Western understanding of writing, and also of consciousness, is a certain repression of an anxiety towards death. The necessary condition of death, so to say, is suppressed in order to claim presence in speech and self-knowledge through consciousness. Differance in such a context can be seen as a possibility of death that can never be actualized for the idealized fullness of self's consciousness, or for any certainty of meaning in language. Meaning in other words, is death. Just like death, one's own death keeps deferring in one's own consciousness, similarly meaning in language, or in consciousness is ever in a state of deferring and differing, that is, characterized by differance.

Differance as an attempt to overcome a certain anxiety of the fear of death can be related to the understanding of anxiety in another Jewish thinker, Sigmund Freud, whom Derrida acknowledges as one of his predecessors in contributing towards the advent of deconstruction and postmodernism. Anxiety for Freud, 'the fundamental phenomenon and main problem of neuroses' is the fear of the otherness within the self. The fear of death is the fear of the absence or death of the desired other. In Henry Staten's words:

No one can experience his own death: only others can experience one's death. The death we know, the death that is truly ours, is the death of the other, the one who dies while we live on.

Yet this death that is known is one that is somehow outlived. The other death, the one which is not outlived - our 'own' death, as it is improperly called - is not known. It can be imagined perhaps, but the death imagined can only be imagined as non death, as though our consciousness had survived the moment of cessation and could know what this cessation looked like. ${ }^{71}$

70 Derrida, Speech and Phenomena, trans. David B. Allison (Evanston: Northwestern University Press, 1973), 54.

${ }^{71}$ Henry Staten, Wittgenstein and Derrida (Lincoln: University of Nebraska Press, 1986), 153-154. 
The Cogito's definitional inability to experience death, the absolute absence, restricts any possibility of full self-knowledge, the knowledge of absolute presence, of absolute meaning. The man who imagines his own death, says Lucretius, does not 'oust and pluck himself root and branch out of life, but unwittingly makes something of himself linger on'. Pity for one's own death means that he 'does not banish himself from the scene nor distinguish sharply enough between himself and that abandoned carcass. He visualizes that object as an on looker ... He does not see that in real death there will be no other self alive to mourn his own decease ${ }^{, 72}$.

But one could always ask how Lucretius himself would ever come to know that 'in real death there will be no other self alive to mourn'. This kind of a claim submits to a Cartesian epistemology that claims knowledge without actually having it. And this is where deconstruction should only be seen as only a critique of claims to universal validity and not a separate epistemology, one as tasawwuf would claim for itself. Differance as an unending differing and deferring of death or meaning can at the most be seen as a corrective to such claims as that of Lucretius of treating phenomena that evade apprehension in rational terms as though fully comprehended through reason. Differance, itself a rational exposition, exposes the limits of rational epistemology through opening an arena of uncertainty without any claims otherwise. Death is neither to come nor is it not to come, meaning is neither there nor is it not there. This indeterminacy, an uncertainty in the face of illegitimate certainty, one must acknowledge, is purely a product of reason and philosophy itself.

If Differance is the possibility of death as it exists in human consciousness, this possibility is always uncertain. And this is the only possibility philosophy can offer. In what sense can such a term be attached to a term that within the Sufi tradition signifies absolute certainty? Rumi voices again the epistemological break of tasawwuf from philosophy:

The way of him that has passed away is another way

Because sobriety/ self consciousness is another $\sin ^{73}$

Differance corresponds to death and meaning in the same way, as Blooms observes '...Kabbalah can teach contemporary interpretation ... that meaning ... is always wandering meaning, even as the belated Jews were a wandering people. Meaning wanders, like human tribulation, or like error, from text to text, and within a text, from figure to figure'. This uncertainty and attitude of avoidance of death, the Qur'an, the Book that regulates all Sufi epistemology, associates as a characteristic feature with the Jews:

'Say: "O ye that stand on Judaism! If ye think that ye are friends to God, to the exclusion of (other) men, then express your desire for Death, if ye

\footnotetext{
${ }^{72}$ Lucretius, On The Nature of the Universe, trans. R. E. Latham, (Baltimore: Penguin Books, 1971), 122-123. Quoted here from Staten, Wittgenstein and Derrida, 153-154.

${ }^{73}$ Rumi, The Mathnawi, I/ 2200.
} 
are truthful!" But never will they express their desire (for death), because of the (deeds) their hands have sent before them! And God knows well those that do wrong. Say: "The death from which you flee will truly overtake you: then will ye be sent to the Knower of things secret and open: and He will tell you (the truth of) the things that ye did!"(62: 6-8)

Death in the Qur'an, in contrast to the postmodern deconstructive/Judaic gesture of deferring and uncertainty, has been associated with yaqin (certainty). In the last verse of Al Hijr (And serve thy Lord until there comes unto thee the Hour that is certain), and in the forty seventh verse of Al Muddassir ["until there came to us (the Hour) that is certain"] the word yaqin (certainty) has invariably been interpreted as Death. Not only that, but the term in Ibn Arabi, al haqq, that Almond so fondly associates with Derrida's Differance, the Qur'an uses in association with death: "And the stupor of death will bring truth: "This was the thing thou was trying to escape" (50: 19). If one agrees that tasawwuf draws its epistemology from the Qur'an instead of philosophy, then one can imagine why and how Almond would see the effects of both differance and al haqq resulting in a similar sort of 'confusion'.

Ignoring the proper epistemological contextualizing of both the terms, Almond inevitably reaches 'confusion'. It is certainly a measure of Almond's confusion that he can be convinced of the 'contradiction' and 'disparity between the theory and practice' of Ibn Arabi (along with Derrida). He comes up with this astonishingly remarkable observation that "the words "literal sense" in Ibn Arabi do not possess any real meaning, ${ }^{74}$. As far as Derrida is concerned, this may be true in placing him within his proper epistemological context, as we will presently show. If we are to agree with William Chittick, Almond tells the readers, that "Ibn Arabi displays tremendous reverence for the literal text', then 'an entirely new notion of "literality" has to be constructed...'

Let us put here a notion of literality which might be something new for Almond, for we missed its mention in his book. This new notion of literality will certainly help determine whether Ibn Arabi would have any reverence for the literal sense. For this 'new' notion of the literal let us refer to Herald Bloom again:

Every poetic trope is an exile from literal meaning, but the only homecoming would be the death of figuration and so the death of poetry, or the triumph of literal meaning, whatever that is ... the trope defends against literal meaning in the same way that psychic defenses trope against death. Literal meaning, where belated is so acute in poetic consciousness, is synonymous with repetitioncompulsion, and so literal meaning is thus seen as a kind of death,

\footnotetext{
${ }^{74}$ Almond, Sufism and Deconstruction, 85.
} 
even as death itself seems the most literal kind of meaning. ${ }^{75}$ (My italics)

If literal meaning is 'a kind of death', then the Sufi approach to it can be measured from the Sufi approach to death. Rumi tells us that aulia, the friends of Allah, are the people who "have died before death ... without an iota of being left in them ${ }^{, 76}$. He further says in the Mathnawi that what he means by death is "not such a death that you will go into a grave/ (But) a death consisting of transformation, so that you will go into a light'. ${ }^{77}$ If literal meaning is a kind of death, then this kind of death is not so literal, rather it destroys the usual distinction between the literal and the figurative, between zahir and batin and accommodates both in the unitary simplex of the Sufi experience. This might again seem a deconstructive gesture, but the neoorientalist and postmodernist tendency towards the figurative at the expense of the literal remains the differentiating factor between the two epistemologies.

Almond finds contradiction in Ibn Arabi because in theory, Ibn Arabi seems to him to be rather faithful to the literal, whereas in his practice, Almond finds him committed to the tropological. This is Almond's own reading of Ibn Arabi which can be put against other readings producing rather different conclusions. But Almond links Ibn Arabi with deconstruction on the basis of his practice and passes a bold judgment on him to side him with the non-literalists. This is a characteristic postmodern gesture that bears the traces of modernity: if Muslims are lacking in practice, there must be something wrong with the thought, that is, on the basis of a certain instance of practice, and even that in Ibn Arabi's case, Almond has treated with considerable critical callousness (for example, claiming to give 'real' meanings of what Ibn Arabi said) ${ }^{78}$, the whole paradigm of placement has to be changed. This attitude is in total contrast with the attitude of the Sufis themselves, like Mujaddid Alf Thani, who only express 'surprise' at the presence of unacceptable contradictions and accept the Sheikh among the maqbulin (the accepted). ${ }^{79}$

${ }^{75}$ Harold Bloom, Kabbalah and Criticism, 89-90.
${ }^{76}$ Rumi, Fihi ma Fih, trans. W. M. Thackston Jr., Signs of the Unseen, The Discourses of
Jalaluddin Rumi, 76.
${ }^{77}$ Rumi, The Mathnawi, VI/ 739 .
${ }^{78}$ See an example of this authoritative treatment of the Sheikh: '... when Ibn Arabi quotes
the hadith "O Lord, increase my perplexity concerning you"... what he is really asking is : O
Lord, confuse and confound the simplistic limitations I have attempted to cage You within'.
Almond in doing this is not only interpreting Ibn Arabi on his own authority but is claiming
to interpret the hadith itself. Sufism and Deconstruction, 42.
${ }_{79}$ Ahmed Sarhindi Mujaddid Alf Thani, Maktubat Hazrat Mujaddid Alf Thani, trans. Mawlana Syed Zawwar Hussein Shah, (Karachi: Idarah Mujaddidyah, n. d.), letter no. 266, vol. 1 part 2, 251. 